\title{
The Dissemination of the Digital Humanities within Research on Biblical, Early Jewish and Christian Studies
}

\author{
Claire Clivaz and Sarah Bowen Savant
}

This third volume of Digital Biblical Studies (DBS) represents a turning point in the birth of the series, as well as in the dissemination of the Digital Humanities within "Biblical, Early Jewish and Christian Studies". The title acknowledges the three research groups devoted, since 2012 and 2013, to the Digital Humanities at the annual meetings of the Society of Biblical Literature (SBL), the international SBL (ISBL), and the European Association of Biblical Studies (EABS). Our introduction will comment on the development of the Digital Humanities and offer a preview of the contents of this volume.

The DBS series is now fully established in the academic landscape. In 2013, a first volume pre-existent to the series was published through Brill edited by Claire Clivaz, Andrew Gregory and David Hamidović, Digital Humanities in Biblical, Early Jewish and Early Christian Studies. ${ }^{1}$ It was entitled exactly as the first research group on the topic created at the EABS 2012 in Amsterdam, then at the SBL and ISBL 2013, and included papers presented in these research groups. After six years as co-chairs of the annual sBL DH section, Clivaz and Hamidović will pass the lead in 2019 to Garrick Allen and Paul Dilley, and join the steering committee members, as a new stage in the field begins. But it is these research groups that have brought our first articles to the DBs series. ${ }^{2}$

We have generally considered the title Digital Humanities in Biblical, Early Jewish and Early Christian Studies to be too long and quite heavy, but at the

1 Clivaz, Claire, Gregory, Andrew, Hamidović, David (eds), in collaboration with Schulthess, Sara, Digital Humanities in Biblical, Early Jewish and Early Christian Studies (Scholarly Communication 2), Leiden: Brill, 2013.

2 Volume DBs 2: Bigot Juloux, Vanessa, Gansell, Amy Rebecca, di Ludovico, Alessandro (eds.), Cyberresearch on the Ancient Near East and Neighboring Regions: Case studies on archaeological data, objects, texts and digital archiving (DBS 2), Brill, 2018. 
same time, we have favoured an explicit description of our subject. Indeed, the intention in creating our research groups was to link together fields that are often distinct. Regarding the discussion about categories of corpora in Ancient Jewish and Christian texts, our research groups have provided since 2012 open spaces to consider the impact of the new medium of digital writing. We believe that our efforts exemplify the potential of digital scholarship as described by John Shaw: "Scholars traditionally begin projects by figuring out what the good research questions are in a given field, and connecting with others interested in the same topics; they then gather and organize data; then analyze it; and finally, disseminate their findings through teaching or publication. Scholarship in a digital environment raises questions about every aspect of this process. For example, in gathering and organizing data". ${ }^{3}$ In other words, the Humanities studied with digital methods and sources can look quite "messy" in comparison to traditional Humanities scholarship, changing the order of the research steps, raising questions at least as often as bringing answers, and testing tools without advance knowledge of their full methodological implications.

If somebody or something has to plead "guilty" for this apparently messy way of working, the main instigator is the digital medium itself. Indeed, as Roger Chartier demonstrated, the writing medium has historically deeply influenced ideas and concepts, and the digital turn represents the greatest change since the passage from the scroll to the codex. ${ }^{4}$ As he summarizes, "the cross between the two systems that governed previous reading material (the volumen and then the codex) produces, in fact, an entirely new relationship with the text. Thanks to these mutations, the electronic text is able to allow the realization of the never-ending dreams of conquering all knowledge that preceded it". ${ }^{5}$ In this relationship to textuality, the rhythm of data production and publishing is reshaping Humanities research profoundly. The digital world allows data to be constantly updated, openly accessible online, and in various forms. Publishing formats can be short syntheses of datasets in blogs, videos,

3 Shaw, John, "Humanities, Digitized. Reconceiving the study of culture," Harvard Magazine, May-June 2012, 40-44, 73-75, <http://harvardmag.com/pdf/2012/05-pdfs/0512-40.pdf >, accessed on 10/04/19, here p.42.

4 See Chartier, Roger, Les métamorphoses du livre. Les rendez-vous de l'édition. Le livre et le numérique, Paris : Bibliothèque du Centre Pompidou, 2001, 8; Vandendorpe, Christian, From Papyrus to Hypertext: Toward the Universal Digital Library, trans. Scott, Phyllis Arnoff, H. [Topics in the Digital Humanities], Urbana (IL), Champaign (IL): University of Illinois Press, 2009, 127 .

5 See Chartier, Roger, "Lecteurs et lectures à lâge de la textualité électronique," Texte-e: Le texte à l'heure de l'Internet, Paris: Bibliothèque Publique d'Information, 2003, here p. 23 (our translation). 
short posts or draft papers, social media, even before the research is completed and peer-reviewed. Peer-reviewed journals like New Testament Studies now allow authors to reference blogs of individual scholars. ${ }^{6}$

Questions relating to expertise and evaluation are consequently at stake in such a situation, and challenges are raised by open access publishing. For example, new ways of publishing are changing the speed with which data is made available, and also the ways that peer review works. Just take for example the Journal of Data Mining \& Digital Humanities: it requests from authors that they deposit prior to peer review their articles in open repositories, such as HAL. ${ }^{7}$ This means that, effectively, the article is available online as soon as it is submitted, with the label of the journal attached to it ${ }^{8}$. Such innovations in practices will require the peer-review process to evolve: it can be considered more and more as a potential multi-layered phenomenon, with different steps in time. ${ }^{9}$

"Rhythm" is consequently a key-word and concept to observe the changes happening in Digital Humanities research. If we look at the great but unfortunately lesser-known work of the French thinker and writer Henri Meschonnic, we can understand why rhythm is a key concept at the crossroads of written/ literary production, data production and publication, and the social performances of the scholar available in talks and videos online. Throughout all of Meschonnic's work, he highlighted the importance of orality, and as a linguist

6 See Emmel, Stephen, "The Codicology of the New Coptic (Lycopolitan) Gospel of John Fragment (and its Relevance for Assessing the Genuineness of the Recently Published Coptic 'Gospel of Jesus' Wife' Fragment)," 22/06/2014, <http://alinsuciu.com////guest-post-stephenemmel-the-codicology-of-the-new-coptic-lycopolitan-gospel-of-john-fragment-and-its-rele vance-for-assessing-the-genuineness-of-the-recently-published-coptic-go-/>, accessed March 26, 2018; quoted by Gathercole, Simon, "The Gospel of Jesus' Wife: Constructing a Context," New Testament Studies 61, 2015, 292-313, here p. 292, footnote 1; <https://doi.org/10.1017/ Soo28688515000107>, accessed on 10/04/19.

7 <https://hal.archives-ouvertes.fr>, accessed on 10/04/19.

8 Clivaz, Claire, Schulthess, Sara, Sankar, Martial, "Editing New Testament Arabic Manuscripts on a TEI-base: fostering close reading in Digital Humanities", first published in 2016 on HAL while submitted to a special JDMDH number on Computer-Aided Processing of Intertextuality in Ancient Languages, <https://hal.archives-ouvertes.fr/hal-01280627>, accessed on 03/06/18. The accepted final version was published in 2017: Clivaz, Claire, Schulthess, Sara, Sankar, Martial, "Editing New Testament Arabic Manuscripts on a TEI-base: fostering close reading in Digital Humanities", Journal of Data Mining \& Digital Humanities, Special issue (ComputerAided Processing of Intertextuality in Ancient Languages), Episciences.org, 2017, 1-6, <https:// jdmdh.episciences.org/paper/view?id=3700 $>$, accessed on 10/04/19.

9 For a development on this question, see the chapter "community-based filtering" in Fitzpatrick, Kathleen, Planned Obsolescence: Publishing, Technology, and the Future of the Academy, New York, NYU Press, 2009, <http://mcpress.media-commons.org/plannedobsolescence/one/ community-based-filtering/>, accessed on 10/04/19. 
as well as a poet, he considered that writing is not opposed to orality, just as signification is not opposed to sound. Notably influenced by the reading and translation of Hebrew biblical texts, he was struck by the numerous marks of orality inscribed within Hebrew texts, and in 1995, he wrote an essay about the notion of "rhythm" in writing, Politique du rythme, politique du sujet. ${ }^{10}$ The subject who is speaking always remains related to a performance, to a social act. The speaking subject is a "body-social-language", in writing as well as in speaking. Consequently, rhythm constitutes the principal operator of sense in the discourse, and it produces the meaning: "Le sens étant l'activité du sujet de l'énonciation, le rythme est l'organisation du sujet comme discours dans et par son discours".11 If, as he argues, rhythm organizes and animates discourse, either written or spoken through the subject who is always involved in a social performance (whatever means of expression he/she uses), the same should extend to other forms of discourse. This suggests that the concept of rhythm can also be usefully employed to map transformations within the Humanities and digital culture, including the rhythm that animates data production, data mining, and data editing and publishing.

Given the rather fast rhythm of digital culture, it might appear surprising to initiate a series that includes traditional paper books, a process that requires time. But we believe that Humanities knowledge still benefits from the reflection built into the processes of paper book production, and likewise, that paper books will endure. Still, our practices are in deep transformation, and, without wishing to be the Pythia, we hope that the day will soon come when scholars no longer think in terms of a distinct field called the "Digital Humanities," but rather expect the Humanities to be studied using digital methods and sources. We only have to consider the history of computing. No one today would speak about a "digital computer", an expression that we would consider to be redundant, whereas it once was common to speak about a "digital computer". The first written trace of this expression can be found in the scientific report written in 1942 by George Robert Stibitz, according to Bernard Williams' inquiry. ${ }^{12}$ In 1950, Alan Turing also used it in his famous article "Computing Machinery and Intelligence". ${ }^{13}$

10 Meschonnic, Henri, Politique du rythme, politique du sujet, Lagrasse : Verdier, 1995.

11 Meschonnic, Henri, Critique du rythme. Anthropologie historique du langage, Lagrasse: Verdier, 1982, 217.

12 Williams, Bernard, Computing with Electricity, 1935-1945, PhD Dissertation, University of Kansas, 1984, USA: University Microfilms International, 1987, 310. See also the monograph of Dennhardt, Robert, The Term Digital Computer (Stibitz 1942) and the Flip-Flop (Turner 1920), Norderstedt: Grin Verlag, 2016. <http://phil415.pbworks.com/f/TuringComputing.pdf>, for example p.50, accessed on 10/04/19. 
Indeed, we can expect the Humanities to be entirely digitized within some years, at which point we will no longer need to mention "the digital" as such. ${ }^{14}$ With this volume, we therefore affirm that the Humanities will persist in its core areas of enquiry since knowledge, social interactions and political challenges continue to require deep practices of interpretation. As the French thinker Yves Citton underlines it, interpretation is the key skill that our societies urgently need: "J'aimerais suggérer que nos 'sociétés de la connaissance' méritent d'être analysées comme étant avant tout des cultures de l'interprétation et que la remise au premier plan des questions d'interprétation doit nous conduire à revoir profondément à la fois notre vision des interactions sociales, notre cartographie des savoirs, la structuration de nos institutions d'éducation supérieure et la formulation de nos revendications politiques". ${ }^{15}$ Let's hope that digitized Humanities will listen to such a call and play their important cards in the knowledge play an important part in needing societies' needs.

\section{$2 \quad$ Content of the Volume}

The volume presents articles enlightening the "the availability of manuscripts to paradigms and practices of textual scholarship" (Liv Ingeborg Lied) ${ }^{16}$. Her essay and this entire volume can be approached as part of the so-called "Third Wave Digital Humanities Studies", "perceived as studies exploring the effect of the digital turn on the practices, epistemologies and paradigms of Humanities scholarship". ${ }^{17}$ The maturation of data visualization and mining represents a current media shift that can be contextualized within long-term media history, "seeing the turn to digital images as yet another remediation of materially extant texts in manuscripts", as Ingeborg Lied explains ${ }^{18}$. To illustrate this turn toward digital images, the reader should not be surprised to find a special emphasis on manuscripts in this volume. Indeed, as pointed by Claire Clivaz in 2016, religious studies in Antiquity remain mainly textual Humanities: their "focus is clearly on texts and textuality, which have been the center of Jewish and Christian studies for centuries, while archeology and art history were

14 For a full discussion of this point and the general meaning - in French - of Humanités, see Clivaz, Claire, "Lost in translation? The odyssey of 'digital humanities' in French", Studia Uвв Digitalia 62, 2017/1, 26-41, <http://digihubb.centre.ubbcluj.ro/journal/index.php/ digitalia/article/view/4/18 1>, accessed on 10/04/19.

15 Citton, Yves, L'Avenir des Humanités. Économie de la connaissance ou culture de l'interprétation?, Paris : La Découverte, 2010, 21.

16 See p. 17.

17 See p. 17 .

18 See p. 17 . 
considered side disciplines. Data visualization and the resulting digital storm will surely contribute to progressively transforming" their content. ${ }^{19}$

Such an evolution will still take time, and it can already be considered as an important step to present a volume that proposes to look at the manuscript data, at the same time or even may before reading them. Even for the Humanities considered in general, the merits of data visualisation are not evident. For example, Johanna Drucker has qualified in 2011 the graphical tools as a "Trojan horse": "As digital visualization tools have become more ubiquitous, humanists have adopted many applications such as GIS mapping, graphs, and charts for statistical display that were developed in other disciplines. But, I will argue, such graphical tools are a kind of intellectual Trojan horse, a vehicle through which assumptions about what constitutes information swarm with potent force. These assumptions are cloaked in a rhetoric taken wholesale from the techniques of the empirical sciences that conceals their epistemological biases under a guise of familiarity". ${ }^{20}$ Exploring this tricky aspect of visualisation for the textual Humanities, Pete Phillips' article in our volume puts the Ancient religions readers in front of what becomes everyday more obvious: the fragility of the text.

Phillips maps the power of visual culture for Christianity, including recent input in the life of the Churches: "both Vatican II and the contemporary papacy of Pope Francis signal, in different but consonant ways, a powerful shift back to the gestalt experience of the visual - that moment of recognition when the visual reveals something profound about wider culture".21 The role of perceptions, senses, emotions is indeed important, according to David Morgan: "Visual culture refers to all the means of constructing life-worlds - attitudes, conceptual schemata, emotion, social dynamics, institutions. In addition to images, it is ways of seeing as well as the practices that deploy images. The study of visual culture is not just about pictures, but also powerful forms of embodiment, that is, the gendered, sexual, racial, ethnic, sensuous characteristics of perception and feeling that constitute primary forms of organizing human values". ${ }^{22}$ In the transformation provoked in Biblical, Early Jewish and

19 Clivaz, Claire, "Introduction. Digital Humanities in Jewish, Christian and Arabic traditions", Journal of Religion, Media and Digital Culture 5, 2016,1-20, here p. 5-6, <https://brill. com/downloadpdf/journals/rmdc/5/1/article-p1_1.xml>, accessed on 10/04/19. Drucker, Johanna, "Humanities Approaches to Graphical Display", $D H Q$ 5, 2011/1, §1, <http://www.digitalhumanities.org/dhq/vol/5/1/oooog1/oooog1.html>, accessed on 10/ $04 / 19$.

$21 \quad$ See p. 32.

22 Morgan, David, The Embodied Eye, Religious Visual Culture and the Social Life of Feeling, USA: University of California Press, 2012, 31, quoted p. 33 below. 
Christian studies by the wave of the data visualization and mining, this volume represents only a piece of the mosaic, but hopes to help the readers to appreciate the richness of this turn.

Our volume is built in three sections. The first section presents two overview articles on the topic (Ingeborg Lied and Peter M. Phillips) and two articles that illustrate specific cases (Brent Landau, Adeline Harrington and James C. Henriques, and Stephen J. Davis). The second section is focused on data mining, with two articles on quantitative analysis and comparison (Thibaut Clérice and Matt Munson, and Paul Robertson), one article about natural language processing (Brett Graham) and one article about electronic transcription (H.A.G. Houghton). Formally speaking, it can be noticed that these articles solicit visualisation not only at the conceptual level in their texts, but also practically through tables and patterns, that present other ways to look at the data. The third section focuses on communication, with two articles on teaching (Heather Dana Davis Parker \& Christopher A. Rollston, and Jennifer Aileen Quigley \& Laura Salah Nasrallah), one article about communication inside of scholarship and the notion of forgery (James F. McGrath), and finally a project report (Bradley C. Erickson). The three sections together illustrate Paul Dilley's definition of digital philology, as "new scholarly interpretive practices that both produce and are enacted by the transfer of texts from manuscripts and the printed page to digital files subject to computational analysis and visualization" 23 .

In Part 1, Lied and Phillips present overviews about of a visualization and its epistemological consequences on textuality. In "Digitization and Manuscripts as Visual Objects: Reflections from a Media Studies Perspective", Lied explores the outcome of digitization of manuscripts in libraries as an ongoing media shift. She considers the increased presence of online manuscripts and the changes they provoke in editing practices. She ponders what are "the academic reader's expectations to the content and format of critical editions?". ${ }^{24}$ At the end of the article, the reader will have an overview of editing practices and readers' expectations when manuscripts can be seen online. In "The Power of Visual Culture and The Fragility of the Text", Phillips dares to raise the ultimate question that stands behind visualisation: the fragility - and potentially the diminution or even disappearance - of the text itself. He evokes the European social imaginary and the "pictural turn" in contemporary society. Three visual

23 Dilley, Paul, "Digital Philology between Alexandria and Babel", in: Ancient Worlds in Digital Culture (Digital Biblical Studies 1), ed. Clivaz, Claire, Dilley, Paul, Hamidović, David, in collaboration with Apolline Thromas, Leiden: Brill, 2016, 17-34; here p. 18.

24 See p. 20. 
explorations of the Biblical text are discussed: an exhibition of the Lindisfarne Gospels, celebrity tweets that countain biblical references or verses, and the recent Hollywood blockbuster film, Noah, directed by Darren Aronofsky.

Next, the reader will find two articles concerning the latest manuscript visualization technologies. In “'What no eye has seen': Using a digital microscope to edit papyrus fragments of early Christian apocryphal writings", Brent Landau, Adeline Harrington and James C. Henriques present the technology of the digital microscope that can "take high-resolution photographs of individual letters under magnification, and some models also allow for photography in the ultraviolet and infrared light spectra" 25 . This technology is applied to three fragmentary early Christian writings: P.Oxy. 210 (a possible fragment of an apocryphal gospel); P.Oxy. 4009 (which may or may not be part of the Gospel of Peter); and P.Oxy. 4469 (an amulet containing part of King Abgar's letter to Jesus). The co-authors consider the importance of interdisciplinary teams and the inclusion of members with such professional skills. Next, in "Manuscripts, Monks, and Mufattishīn: Digital Access and Concerns of Cultural Heritage in the Yale Monastic Archaeology Project", Stephen Davis introduces readers to digital methods and Egypt's monasteries: what does it mean exactly to see monastery manuscripts and to make them visible for everybody online? Procedures, access, photos: all steps are evoked in this article that presents the cases of fragments in the Church of St. Shenoute at the White Monastery near Sohag, and the cataloguing Coptic and Arabic manuscripts at the Monastery of the Syrians in Wādī al-Națūn.

Part two of the volume illustrates the developments of data mining in the study of Ancient Jewish and Christian manuscripts and electronic transcriptions and/or edited texts. Clérice and Munson and Graham's articles concern recent developments in manuscripts data mining. In "Qualitative Analysis of Semantic Language Models", Thibaut Clérice and Matt Munson aim to "make this widely used and accepted task [of automatically extracting semantic information] more useful outside of purely linguistic studies by considering how one can qualitatively assess the results returned by such algorithms". ${ }^{26}$ They claim that the critical projection of algorithmic results belongs to the Humanities core skills, an affirmation that will surely be debated in the following works on the topic, as it deserves. In "Using Natural Language Processing to Search for Textual References", Brett Graham presents a part of his PhD research "how recent advances in NLP technology can be harnessed to search for

25 See p. 118.

26 See p. 87. 
allusions and influences"27. He presents a generic NLP algorithm, including a set of syntax rules for textual references, "that can be used to detect any type of textual reference in any type of text (or even an oral allusion to an oral speech)".28

The following two articles focus on New Testament writings. In "Electronic Transcriptions of New Testament Manuscripts and their Accuracy, Documentation and Publication", Hugh Houghton describes and discusses the main transformations of digital editing as embodied in the Novum Testamentum Graecum Editio Critica Maior. ${ }^{29}$ He points to the automatically generated apparatus and to new procedures involved in Greek New Testament editing: "In particular, [this article] considers the accuracy and transparency of the current transcription process for this edition, suggesting that proofreading is an important stage even if a double-blind approach has been used for the initial transcriptions and arguing for a fuller use of the TEI Header to describe the source and limitations of the transcription". ${ }^{30}$ In a creative way, he explains the recent choice of the consortium to apply Creative Commons Licenses to its work. In "Visualizing Data in the Quantitative Comparison of Ancient Texts: A Study of Paul, Epictetus, and Philodemus", Paul Robertson focuses on Paul's letters, Epictetus' Discourses, and Philodemus' On Piety and On Death. He explores and applies the notion of "polythetic classification" classification to these corpora: "These forms of visualization then allow for an empirical, transparent form of comparison between texts. Qualitative analysis can productively supplement this quantitative analysis, matching specific literary and conceptual context with second-order data analysis". ${ }^{31}$

The third part, finally, considers communication of digital methods through teaching and other channels. Two articles focus on teaching challenges for ancient artefacts in a digital culture. In "Teaching Epigraphy in the Digital Age", Heather Dana Davis Parker and Christopher Rollston, treat Semitic epigraphy as delineating "certain aspects of the history of this field and discuss

$27 \quad$ See p. 118.

28 See p. 118.

29 The Novum Testamentum Graecum Editio Critica Maior designates the main editing project of the Greek New Testament: "The first installment of this edition appeared in 1997. The 'Catholic Epistles' (the Epistles of James, Peter, John, and Jude) are now in print. The Acts of the Apostles and - in cooperation with the renowned 'International Greek New Testament Project' - the Gospel of John are currently under preparation. The entire Editio Critica Maior is to be completed by 2030. This project is being supported by the Union of the German Academies of Sciences and Humanities", <https://www.academic-bible.com/ en/home/current-projects/editio-critica-maior-ecm/>, accessed on 10/04/19.

30 See article's abstract on <https://brill.com/abstract/title/34930 $>$.

31 See article's abstract on <https://brill.com/abstract/title/34930 $>$. 
the traditional means of studying ancient texts in light of new technological innovations". ${ }^{32}$ Ancient texts and palaeographic script charts are considered in teaching, and valuable for diverse epigraphic fields. In "HarvardX's Early Christianity: The Letters of Paul: A retrospective on online teaching and learning", Jennifer Aileen Quigley and Laura Salah Nasrallah consider the effect of a M Ooc (Massive Open Online Course) on New Testament teaching about the Pauline letters. It has achieved success and the authors describe what it means for teachers to be seen online in a classroom of thousands of people. The authors present quantitative and qualitative data about course attendance, but the main point is that "MOocs should keep as a key goal the crafting of a public, free, and critical space for students who express a desire, no matter their location on the globe, to learn about and to discuss the Bible". ${ }^{33}$

With James McGrath, what is here to be seen are the complex relationships of scholars with their objects of study. In "Learning from Jesus' Wife: What Does Forgery Have to do with the Digital Humanities?". McGrath comes back to the hard disputed episode of the so-called Gospel of Jesus' Wife. He "sets aside as settled the question of the papyrus' authenticity, and explores instead what we can learn about the Digital Humanities and scholarly interaction in a digital era from the way the discussions and investigations of that work unfolded, and how issues that arose were handled"34. He offers readers the opportunity to consider at a distance what has been at stake in polemics by helping them to see the scholarly debates. Finally, we welcome in this DBS 3 volume a novelty: a project report. We consider that, in the series, it is particularly important to welcome projects reports, because of the rhythm of DH dissemination. Before a project has ended or reach its maturity and can fully be analyzed, there are several steps: the inputs of colleagues, the scholarly discussion is required at each step, and consequently the format of "project report" is acquiring a growing-up dimension in the DH scholarly process. Erickson, with "Synagogue Modeling Project Report: A Multi-faceted Approach to 3D, Academic Modeling", is the first one to test the new format. He "presents a report to address the problems of access, scale, and dimensionality that scholars face when working with material culture". ${ }^{35}$ The readers will find information about photogrammetric and ${ }_{3} \mathrm{D}$ models of the ancient synagogues of Beth Alpha, Sepphoris, and Hammath Tiberius.

$32 \quad$ See p. 189.

33 See p. 218.

34 See article's abstract on <https://brill.com/abstract/title/34930 >.

35 See p. 262. 
We thank warmly all our authors for offering an impressive overview of the topic and the potential of visualisation with/over textuality, and the Swiss National Science Foundation for its open access support to this volume. We express our deepest debt to our editorial assistant, Alessandra Marguerat, who prepared with so much patience and care this volume. Last but not least, our gratitude extends to Brill for its support throughout the birth of this new series, and in particular to Marjolein van Zuylen, Loes Schouten and Liesbeth Hugenholtz.

\section{References}

Bigot Juloux, Vanessa, Gansell, Amy Rebecca, di Ludovico, Alessandro (eds.), Cyberresearch on the Ancient Near East and Neighboring Regions: Case studies on archaeological data, objects, texts and digital archiving (DBS 2), Brill, 2018.

Chartier, Roger, Les métamorphoses du livre. Les rendez-vous de l'édition. Le livre et le numérique, Paris : Bibliothèque du Centre Pompidou, 2001.

Chartier, Roger, "Lecteurs et lectures à lâge de la textualité électronique," Texte-e: Le texte à l'heure de l'Internet, Paris : Bibliothèque Publique d'Information, 2003.

Citton, Yves, L'Avenir des Humanités. Économie de la connaissance ou culture de l'interprétation?, Paris : La Découverte, 2010.

Clivaz, Claire, Gregory, Andrew, Hamidović, David (eds), in collaboration with Schulthess, Sara, Digital Humanities in Biblical, Early Jewish and Early Christian Studies (Scholarly Communication 2), Leiden: Brill, 2013.

Clivaz, Claire, Schulthess, Sara, Sankar, Martial, "Editing New Testament Arabic Manuscripts on a TEI-base: fostering close reading in Digital Humanities", Journal of Data Mining \& Digital Humanities, Special issue (Computer-Aided Processing of Intertextuality in Ancient Languages), Episciences.org, 2017, <https://jdmdh.epi sciences.org/paper/view?id=3700>, accessed on 03/06/18.

Clivaz, Claire, "Lost in translation? The odyssey of 'digital humanities' in French", Studia Uвв Digitalia 62, 2017/1, 26-41, <http://digihubb.centre.ubbcluj.ro/journal/ index.php/digitalia/article/view/4/181>, accessed on 10/04/19.

Clivaz, Claire, "Introduction. Digital Humanities in Jewish, Christian and Arabic traditions", Journal of Religion, Media and Digital Culture 5, 2016, 5-6, <https://brill.com/ downloadpdf/journals/rmdc/5/1/article-p1_1.xml>, accessed on 10/04/19.

Dennhardt, Robert, The Term Digital Computer (Stibitz 1942) and the Flip-Flop (Turner 1920), Norderstedt: Grin Verlag, 2016.

Dilley, Paul, "Digital Philology between Alexandria and Babel", in: Ancient Worlds in Digital Culture (Digital Biblical Studies 1), ed. Clivaz, Claire, Dilley, Paul, Hamidović, David, in collaboration with Apolline Thromas, Leiden: Brill, 2016, 17-34. 
Drucker, Johanna, "Humanities Approaches to Graphical Display", DHQ 5, 2011/1, <http://www.digitalhumanities.org/dhq/vol/5/1/oooog1/oooog1.html>, accessed on 10/04/19.

Emmel, Stephen, "The Codicology of the New Coptic (Lycopolitan) Gospel of John Fragment (and its Relevance for Assessing the Genuineness of the Recently Published Coptic 'Gospel of Jesus' Wife' Fragment)," 22/o6/2014, <http://alinsuciu. com////guest-post-stephen-emmel-the-codicology-of-the-new-coptic-lycopolitangospel-of-john-fragment-and-its-relevance-for-assessing-the-genuineness-of-therecently-published-coptic-go-/>, accessed on 10/04/19.

Fitzpatrick, Kathleen, Planned Obsolescence: Publishing, Technology, and the Future of the Academy, New York, NYU Press, 2009, <http://mcpress.media-commons.org/ plannedobsolescence/one/community-based-filtering/>, accessed on 10/04/19.

Gathercole, Simon, “The Gospel of Jesus' Wife: Constructing a Context," New Testament Studies 61, 2015, 292-313.

Meschonnic, Henri, Politique du rythme, politique du sujet, Lagrasse : Verdier, 1995.

Meschonnic, Henri, Critique du rythme. Anthropologie historique du langage, Lagrasse : Verdier, 1982.

Morgan, David, The Embodied Eye, Religious Visual Culture and the Social Life of Feeling, USA: University of California Press, 2012.

Shaw, John, "Humanities, Digitized. Reconceiving the study of culture," Harvard Magazine, May-June 2012, 40-44, 73-75, <http://harvardmag.com/pdf/2012/05-pdfs/051240.pdf >, accessed on 10/04/19.

Turing, Alan, "Computing Machinery and Intelligence", Mind 49, 1950, 433-46o, <http:// phil415.pbworks.com/f/TuringComputing.pdf >, accessed on 10/04/19.

The Union of the German Academies of Sciences and Humanities", <http://www.aca demic-bible.com/en/home/current-projects/editio-critica-maior-ecm/>, accessed on 10/04/19.

Vandendorpe, Christian, From Papyrus to Hypertext: Toward the Universal Digital Library, trans. Scott, Phyllis Arnoff, H. [Topics in the Digital Humanities], Urbana (IL), Champaign (IL): University of Illinois Press, 2009.

Williams, Bernard, Computing with Electricity, 1935-1945, PhD Dissertation, University of Kansas, 1984, USA: University Microfilms International, 1987, 310. 
PART 1

Visualising the Manuscripts 